\title{
Maioridade penal
}

Arthur KAUFMAN ${ }^{1}$
Cada vez mais freqüente e banalizada, a violência nas grandes cidades vem superando limites quase inacreditáveis, se comparados aos dos anos 1990. Crimes que antes escandalizavam e monopolizavam a opinião pública durante meses, atualmente sucedem-se com a rapidez de uma linha de produção. Pesquisa do Instituto Vox Populi em cinqüenta municípios brasileiros mostra que, em $80 \%$ deles, a criminalidade é vista pela população como um dos três problemas mais preocupantes e, em $40 \%$, a violência é o principal problema. Essa sensação de insegurança do brasileiro tem base real: o número de assassinatos na Capital do Estado de São Paulo, em 1999, foi de 6.638, segundo a Fundação Seade (Sistema Estadual de Análise de Dados). A população demonstra medo até mesmo de sair às ruas: carros blindados, condomínios fechados e, como nos países com tradição de guerra, todo um arsenal mobilizado para que as pessoas se sintam um pouco menos desprotegidas. Um dos fatos mais preocupantes é que a violência cometida contra adolescentes e por adolescentes vem aumentando em proporções inusitadas. No Brasil, pobreza, desemprego, falta de lazer, falta de perspectivas profissionais, narcotráfico, lares desfeitos, alcoolismo e consumo de drogas são sempre os primeiros fatores a serem lembrados como possíveis etiologias da violência, além da corrupção e falta de ética presente em todos os escalões do poder público, configurando uma falha simbólica que gera a total descrença em uma possível punição dos culpados.O nosso Estatuto da Criança e do Adolescente (ECA - Lei n 8.069), criado em 13 de julho de 1990, prevê as seguintes disposições:

Das disposições preliminares: Art. $1^{\circ}$ - "Esta lei dispõe sobre a proteção integral à criança e ao adolescente.”. Art. $2^{\circ}$ - "Considera-se criança, para os efeitos desta lei, a pessoa até 12 anos de idade incompletos, e adolescente aquela entre 12 e 18 anos de idade."

A idade mínima de 18 anos para maioridade penal, prevista pelo Estatuto da Criança e do Adolescente, é estabelecida conforme orientação da ONU. Ocorre que, na época em que foi decidida tal idade, as pessoas de 18 anos eram muito mais ingênuas, mais "crianças" do que nos dias de hoje. Especialmente após a introdução do Novo Código Civil - que outorga plenos 
poderes aos maiores de 18 , considerando-os maiores absolutamente capazes e antecipando a maioridade civil (que até então só ocorria aos 21 anos) - um cidadão de 18 anos há muito já não é criança. Aos 16 já é tido como relativamente capaz, com poderes para trabalhar e, inclusive, escolher seus governantes.

Os crimes praticados por jovens são cada vez mais freqüentes e comuns. Porém, estes crimes não são praticados apenas pelos excluídos e sem perspectivas. Um estudo realizado pela Udemo, o Sindicato de Especialistas de Educação do Magistério Oficial do Estado de São Paulo, mostrou que, em 1999, 89\% das escolas públicas registraram algum tipo de violência. Dos casos analisados, 21,28\% foram de mortes de estudantes e $35,46 \%$ de ameaças de homicídio. Muitos desses jovens são carentes, porém o fato de freqüentarem a escola mostra que eles têm alguma perspectiva de mudança e adaptação à sociedade.

Não obstante, há ainda os casos de crimes cometidos por jovens de classe média, causados, muitas vezes, por irresponsabilidade e alienação, tais como o famoso caso do índio pataxó Galdino Jesus dos Santos, assassinado por cinco jovens, porque pensavam tratar-se de um mendigo, e o dos estudantes que mataram, a pancadas, um garçom em Porto Seguro.

Quando um adolescente pratica uma infração mediante grave ameaça ou violência, e sendo ele um infrator reincidente, pode estar indicada, segundo o Artigo 112, a internação em estabelecimento educacional. Diz o Artigo 121, parágrafo $3^{\circ}$, no entanto, que "em nenhuma hipótese o período máximo de internação excederá a três anos”.

A psiquiatria da infância e da adolescência descreve, porém, como um de seus quadros mais graves o chamado Transtorno de Conduta (TC), caracterizado por um padrão repetitivo e persistente de conduta antisocial, agressiva ou desafiadora, por no mínimo seis meses. A presença de sintomas de TC na infância é um mau sinal, pois prevê delinqüência na vida adulta. Quanto mais intenso o comportamento agressivo na infância, maior a probabilidade de ocorrer comportamento delinqüente ou francamente criminoso na fase adulta. O TC pode ter início já aos cinco ou seis anos de idade, mas habitualmente aparece ao final da infância ou início da adolescência. $\mathrm{O}$ início precoce prediz um pior prognóstico e um risco aumentado de Transtorno da Personalidade Anti-Social (CID 301.7) na vida adulta.

Os portadores de problemas graves de personalidade, tais como a sociopatia e a psicopatia, não costumam beneficiar-se por medicações, e atividades como sócio e psicoterapia têm efeito bastante limitado, ao contrário do que ocorre com pacientes neuróticos, ou mesmo com psicóticos. É evidente, portanto, que um período de internação de três anos não tem efeito sequer paliativo. Para a perversidade inata, não há tratamento médico, não existe reeducação possível em três anos, e talvez nem sequer em 30.

Na Inglaterra, cada caso é considerado a partir de suas próprias características, independentemente da idade do criminoso. Qualquer crime tem implicações sérias e rigorosas. A idade de responsabilidade criminal no Reino Unido começa aos 10 anos, e são impostas multas por comportamento anti-social a menores a partir de 10 anos de idade.

Entre nós, dada a relativa impunidade dos menores, é freqüente que eles sejam empregados por quadrilhas para diversos tipos de serviços escusos e também para serem responsabilizados por crimes graves perpetrados por maiores. Seria muito interessante que as quadrilhas que utilizam menores realmente tivessem suas penas aumentadas, prática que serviria para coibir o uso destes em atos criminosos, conforme já disposto no Código Penal.

Considero que o menor que disponha de consciência, entendimento, discernimento, intenção, compreensão, ao praticar crime qualificado com requintes de crueldade, deva ser julgado imputável e responder em um primeiro momento dentro do ECA, recebendo assim sanção sócio-educativa e, a partir do momento que atingir a maioridade, deva responder criminalmente.

Não se trata de colocar o adolescente numa penitenciária juntamente com criminosos adultos, mas que haja uma internação sem limite de tempo máximo prédeterminado, uma vez que o número " 3 " (de três anos) nada significa. Seria mais interessante que o menor internado fosse submetido a medidas sócio-educativas e periodicamente fosse visto por uma equipe de saúde mental que avaliasse seu grau de periculosidade. Mas estas medidas deveriam ocorrer dentro de um estabelecimento realmente efetivo, com programas de psico e socioterapia, atividades físicas, esportivas, artísticas etc., prestação de serviços à comunidade, liberdade assistida e inserção em regime de semiliberdade, e não uma instituição que representasse uma escola de crimes, como é atualmente vista a FEBEM, ironicamente chamada Fundação Estadual para o Bem-Estar do Menor.

Nos casos irrecuperáveis, somente seria aplicada ao menor infrator a medida de segurança, que poderia eventualmente mantê-lo confinado pelo maior tempo possível, caso não fosse constatada a cessação de sua periculosidade. 